\title{
Generation of Bis(ferrocenyl)silylenes from Siliranes ${ }^{\dagger}$
}

\author{
Yang Pan ${ }^{1}$, Shogo Morisako ${ }^{2} \mathbb{D}$, Shinobu Aoyagi ${ }^{1}$ and Takahiro Sasamori ${ }^{1,2, *}$ \\ 1 Graduate School of Science, Nagoya City University, Nagoya, Aichi 467-8501, Japan; \\ pan@nsc.nagoya-cu.ac.jp (Y.P.); aoyagi@nsc.nagoya-cu.ac.jp (S.A.) \\ 2 Division of Chemistry, Faculty of Pure and Applied Sciences, University of Tsukuba, Tsukuba, \\ Ibaraki 305-8571, Japan; morisako.shogo.gf@u.tsukuba.ac.jp \\ * Correspondence: sasamori@chem.tsukuba.ac.jp; Tel.: +81-29-853-4412 \\ + Dedicated to Professor Yosuke Yamamoto on the occasion of his 65th birthday. \\ Academic Editor: M.-H. Whangbo
}

Received: 23 November 2020; Accepted: 9 December 2020; Published: 14 December 2020

\begin{abstract}
Divalent silicon species, the so-called silylenes, represent attractive organosilicon building blocks. Isolable stable silylenes remain scarce, and in most hitherto reported examples, the silicon center is stabilized by electron-donating substituents (e.g., heteroatoms such as nitrogen), which results in electronic perturbation. In order to avoid such electronic perturbation, we have been interested in the chemistry of reactive silylenes with carbon-based substituents such as ferrocenyl groups. Due to the presence of a divalent silicon center and the redox-active transition metal iron, ferrocenylsilylenes can be expected to exhibit interesting redox behavior. Herein, we report the design and synthesis of a bis(ferrocenyl)silirane as a precursor for a bis(ferrocenyl)silylene, which could potentially be used as a building block for redox-active organosilicon compounds. It was found that the isolated bis(ferrocenyl)siliranes could be a bottleable precursor for the bis(ferrocenyl)silylene under mild conditions.
\end{abstract}

Keywords: silirane; silylene; ferrocenyl group

\section{Introduction}

Silylenes, i.e., divalent silicon analogues of carbenes, represent highly attractive reactive intermediates due to their considerable potential as building blocks for organosilicon compounds [1-7]. There are several examples of stable silylenes, which are usually stabilized thermodynamically by introduction of heteroatom-based substituents such as amino groups. For example, silicon analogues of $\mathrm{N}$-heterocyclic carbenes (NHCs), $\mathrm{N}$-heterocyclic silylenes (NHSis) [8-17], have been isolated as stable compounds (e.g., I $[8,11]$ and II $[9,13])$ as well as the $N$-substituted cyclic silylene III [14] (Chart 1). However, such thermodynamically stabilized silylenes are too stable, i.e., they usually do not exhibit considerable reactivity as, e.g., building blocks for organosilicon compounds. Conversely, carbon-substituted silylenes, which do not contain a stabilizing electron-donating ligand, are highly reactive due to their considerable electrophilicity on account of their low-lying LUMOs [18-24]. Such highly reactive silylenes can be stabilized kinetically by sterically demanding substituents and subsequently being isolated under an inert atmosphere [25-28]. For example, dicoordinated, carbon-substituted silylenes [29-32] such as IV [29] and V [32] that bear sterically demanding substituents have been isolated and well characterized (Chart 1). However, it is very difficult to synthesize and isolate such silylenes as they usually require laborious and technically exigent synthetic procedures. In this context, easily accessible and bottleable precursors for carbon-substituted silylenes would be an attractive research target. In most cases, silylenes can be generated by reduction of a dihalosilane or photolysis of a trisilane $[4,7,33]$. When the substituents on the central silicon atom offer insufficient steric protection, the products from the aforementioned reactions usually afford complex 
mixtures of oligosilanes. Conversely, most cases of the reduction of sterically hindered dihalosilanes or the photolysis of trisilanes that bear bulky substituents result in the facile formation of a disilene, i.e., the formal dimer of a silylene [33-39]. To prepare a stable silylene precursor, it should thus be required to introduce very bulky substituents on the silicon atom to avoid facile dimerization of the generated silylenes [33]. On the other hand, too bulky substituents can be expected to negatively affect the inherent reactivity of the resulting silylene. In order to find the right balance in this trade-off relationship, transient silylenes with a combination of very bulky and less hindered groups have been designed. Our group has already reported the design and synthetic utility of the sterically demanding 2,5-bis(3,5-di-t-butylphenyl)-1-ferrocenyl ( $\left.\mathrm{Fc}^{*}\right)$ group [40-42], and this group should be an appropriate substituent for bis(ferrocenyl)silylene $\mathbf{1}$ (Chart 1), which bears $\mathrm{Fc}^{*}$ and ferrocenyl (Fc) groups on the silicon center [43]. Silylene 1 can be expected to (i) be very reactive due to its low-lying LUMO level, and (ii) show intriguing redox activity on account of its two ferrocenyl moieties.<smiles>CC(C)(C)CN1NNc2ccccc21</smiles>

I<smiles>C=C1C=C(C)N([Pb])[AlH]N1[Pb]</smiles>

III<smiles>CC1(C)CCC([Si])([SiH3])[SiH2]1</smiles>

IV<smiles></smiles>

$\mathbf{v}$

$\mathrm{R}=\mathrm{Ph}$ or tol

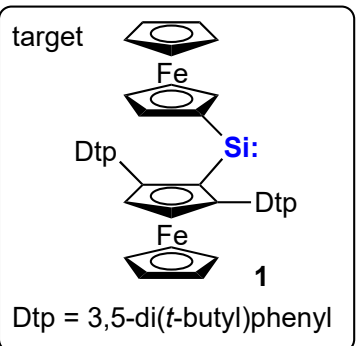

Chart 1. Examples of isolable dicoordinated silylenes.

\section{Results and Discussion}

Reaction of ferrocenyl $(\mathrm{Fc})$ lithium with $\mathrm{SiCl}_{4}$ in toluene resulted in the formation of $\mathrm{FcSiCl}_{3}$ (2) [44], which was used in the following reactions without further purification due to its lability toward moisture. Subsequently, 2 was treated in $\mathrm{Et}_{2} \mathrm{O}$ at r.t. with $\mathrm{Fc}^{*} \mathrm{Li}$ (3) [40-42], which was prepared by the reaction of $\mathrm{Fc}^{*} \mathrm{Br}\left(\mathrm{Fc}^{*}=2,5-\mathrm{bis}\left(3,5-\mathrm{di}\left(t\right.\right.\right.$-buthyl)phenyl)-1-ferrocenyl) with $n$-BuLi in $\mathrm{Et}_{2} \mathrm{O}$, to give the corresponding bis(ferrocenyl)dichlorosilane (4) as a stable orange solid in $44 \%$ yield (Scheme 1 ). Although single crystals suitable for an X-ray diffraction (XRD) analysis could not be obtained due to partial hydrolysis that furnished $\mathrm{Fc}^{*} \mathrm{FcSi}(\mathrm{OH})_{2}$ [45], 4 was characterized by spectroscopic techniques.

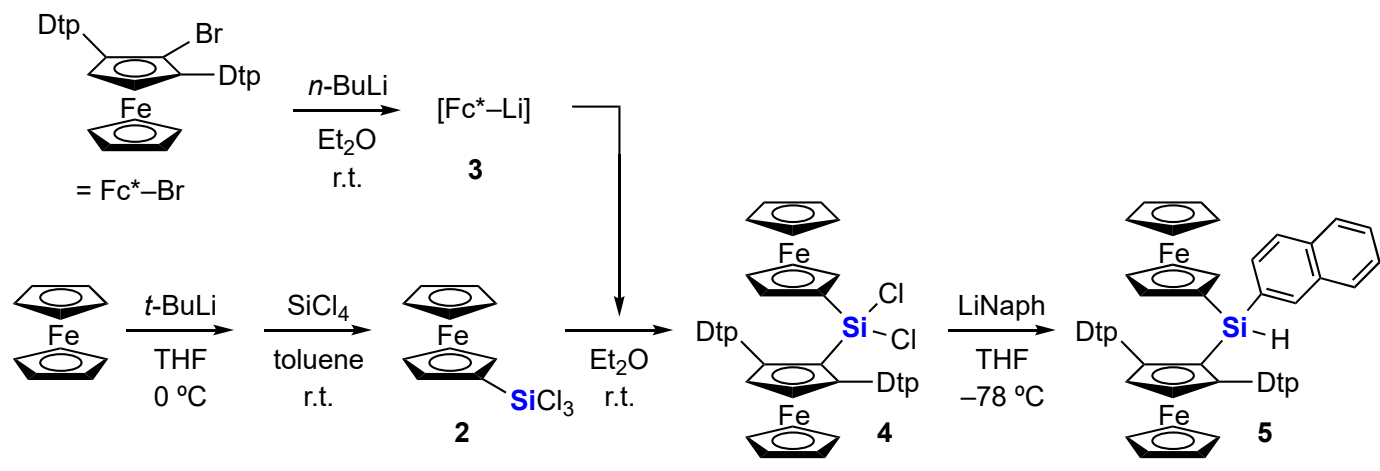

Scheme 1. Preparation of bis(ferrocenyl)dichlorosilane 4 and its reduction with lithium naphthalenide.

As the reduction of diorganodichlorosilanes represents an efficient method for the generation of silylenes [4,33], we speculated that the reduction of bis(ferrocenyl)dichlorosilane 4 might furnish silylene $\mathbf{1}$. However, the generation of $\mathbf{1}$ by the reduction of $\mathbf{4}$ was not observed when common metal reductants such as $\mathrm{KC}_{8}, \mathrm{Na}$, or Li were employed, and only complex mixtures including $\mathrm{Fc}^{*} \mathrm{H}$ were obtained [41]. Conversely, when 4 was treated with lithium naphthalenide in THF at $-78^{\circ} \mathrm{C}$, 2-naphthylsilane 5 was isolated in 30\% yield, and its structure was unambiguously determined by spectroscopic and XRD analyses [46]. The formation of $\mathbf{5}$ should most likely be interpreted in terms of 
a C-H insertion of the reactive intermediate of silylene $\mathbf{1}$ with naphthalene. It should be noted here that it has previously been reported that isolable or transient silylenes react with aromatic compounds such as naphthalene and benzene to give the corresponding silepine or silirane derivatives via $C$ - $C$ insertion and $[1+2]$ cycloaddition reactions, respectively [33,47-50]. Thus, the formation of 5 suggests the unique reaction manner of a silylene with an aromatic compound. Moreover, an isolable zwitterionic silylene has been reported to cleave a C-H bond of benzophenone via a 1,3-hydrogen shift [51,52].

At this point, we suspected that 5 was formed by the reaction of silylene $\mathbf{1}$ with naphthalene via the corresponding [1+2]cycloadduct, silirane 6 , which would be a conceivable intermediate in the reaction of a silylene with naphthalene. In order to clarify the reaction mechanism, the potential energy surfaces (PESs) of the reactions of silylene 1 with naphthalene were calculated at the B3PW91/6-311G(2d,p) level of theory ( $\mathrm{E}_{\mathrm{ZPE}}$ : relative energies including zero-point energy corrections) [53]. The [1+2]cycloaddition of 1 with naphthalene was found to be slightly exothermic $\left(\Delta \mathrm{E}_{\mathrm{ZPE}}=6.12 \mathrm{kcal} / \mathrm{mol}\right)$ to give silirane 6 with a barrier of $\Delta \mathrm{E}_{\mathrm{ZPE}} \ddagger=21.6 \mathrm{kcal} / \mathrm{mol}$. Unexpectedly, silirane 6 was not connected to 5 on the PES in these calculations. Instead, the highly exothermic $\left(\triangle \mathrm{E}_{\mathrm{ZPE}}=37.4 \mathrm{kcal} / \mathrm{mol}\right)$ direct $\mathrm{C}-\mathrm{H}$ insertion pathway of the reaction of $\mathbf{1}$ with naphthalene to furnish 5 was found to have a higher barrier of $\Delta \mathrm{E}_{\mathrm{ZPE}}$ $\ddagger=29.5 \mathrm{kcal} / \mathrm{mol}$. The PES also showed that silirane 6 could give 1 with concomitant elimination of naphthalene via the reverse reaction of the formation of $6\left(\Delta \mathrm{E}_{\mathrm{ZPE}} \ddagger=22.3 \mathrm{kcal} / \mathrm{mol}\right)$. Thus, it can be concluded 5 and 6 should be the thermodynamic and kinetic products, respectively, in the reaction of silylene 1 with naphthalene. At this stage, however, other plausible pathways for the formation of 5 , e.g., by the reaction of dichlorosilane 4 with lithium naphthalenide, which would not include the generation of silylene 1, cannot be excluded from consideration (Scheme 2). However, based on the results of the theoretical calculations, silirane derivatives with a Si-C-C three-membered ring skeleton could potentially be considered appropriate precursors for silylenes such as $\mathbf{1}$.

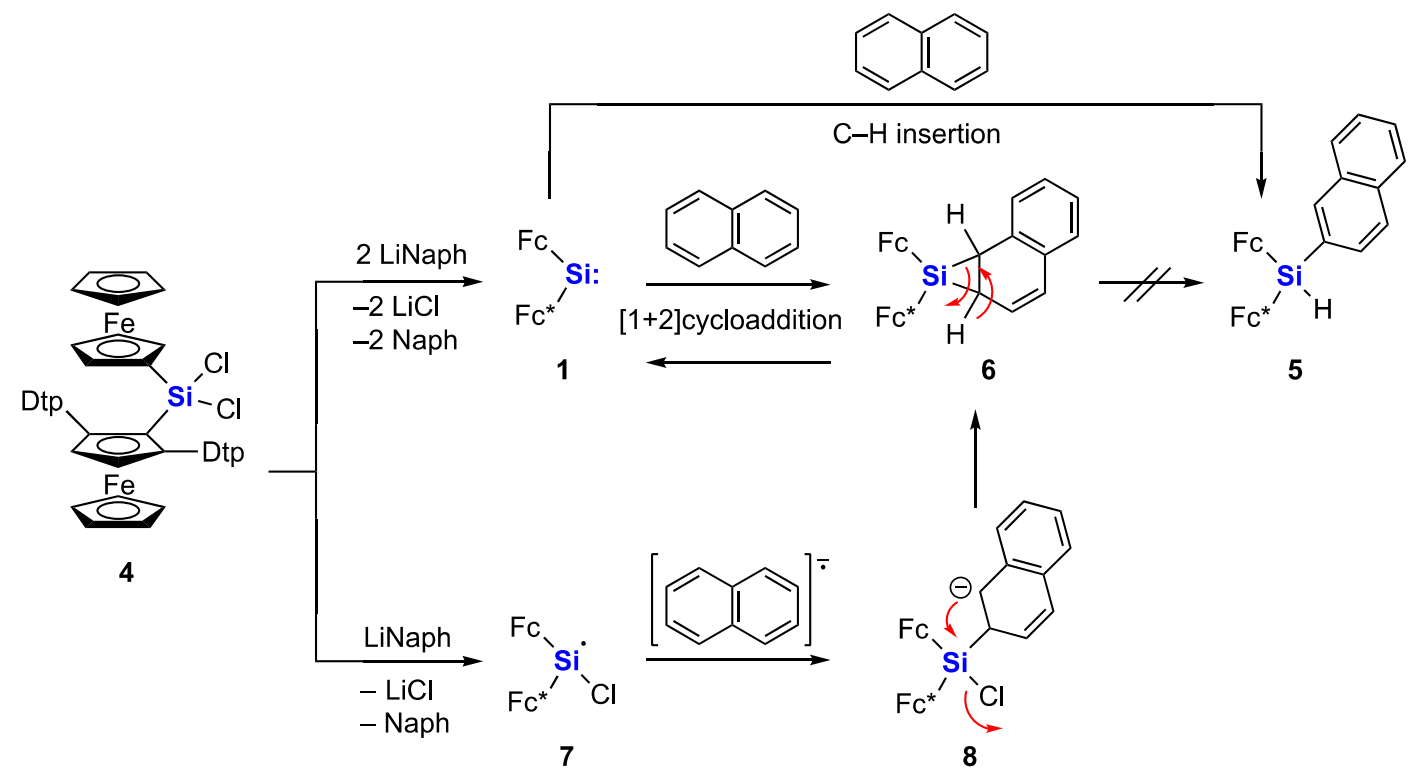

Scheme 2. Plausible mechanisms for the formation of bis(ferrocenyl)(2-naphthyl)silane 5.

When a THF/ $\mathrm{Et}_{2} \mathrm{O}$ solution of dichlorosilane 4 was reduced with sodium in the presence of an excess of cyclohexene and a small amount of naphthalene, a mixture of siliranes $9 \mathbf{a}$ and $\mathbf{9 b}$ was obtained $(86 \%$ yield, $9 a: 9 b=66: 34)$. Even though it was difficult to purify each product by common separation techniques such as gel permeation chromatography (GPC), column chromatography, or recrystallization, a few crystals of $\mathbf{9 a}$ and $\mathbf{9 b}$ were obtained by recrystallization from hexane and pentane, respectively. Thus, siliranes $\mathbf{9 a}$ and $\mathbf{9 b}$ were fully characterized by spectroscopic analyses, while 9a was structurally characterized by XRD analysis [46]. The similar up-field shifted ${ }^{29} \mathrm{Si}$ NMR chemical shifts of $\mathbf{9 a}\left(\delta_{\mathrm{Si}}=-67.2\right)$ and $\mathbf{9 b}\left(\delta_{\mathrm{Si}}=-69.8\right)$ also indicated a silirane structure for $\mathbf{9 b}$, 
suggesting $\mathbf{9 b}$ could be a stereoisomer of $\mathbf{9 a}$ (Scheme 3). At this stage, $\mathbf{9 a}$ and $\mathbf{9 b}$ could not be separated from each other due the close similarity of their chemical properties. Heating a cyclohexene solution of a mixture of $9 \mathbf{a}$ and $\mathbf{9 b}(94: 6$ ratio) shifted the compositional ratio in favor of $9 \mathbf{b}(\mathbf{9 a}: 9 \mathbf{b}=45: 55)$, suggesting that $9 a$ and $\mathbf{9 b}$ represent the kinetic and thermodynamic products in the reaction of $\mathbf{1}$ with cyclohexene, respectively. Both $\mathbf{9 a}$ and $\mathbf{9 b}$ are stable under ambient conditions in the solid state and in $\mathrm{C}_{6} \mathrm{D}_{6}$ solution. Interestingly, the conversion of $\mathbf{9 a}$ to $9 \mathbf{b}$ occurred in the solid state. After heating a mixture of solid $9 \mathbf{a}$ and $9 \mathbf{b}$ (ca. $74: 26$ ) at $120{ }^{\circ} \mathrm{C}$ for $30 \mathrm{~min}$ under reduced pressure, the ${ }^{1} \mathrm{H}$ NMR spectrum of the solid dissolved in $\mathrm{C}_{6} \mathrm{D}_{6}$ showed a $9 \mathrm{a}: 9 \mathrm{~b}$ ratio of ca. 45:55, suggesting a transformation of $9 \mathbf{a}$ to $\mathbf{9 b}$ even in the solid state.

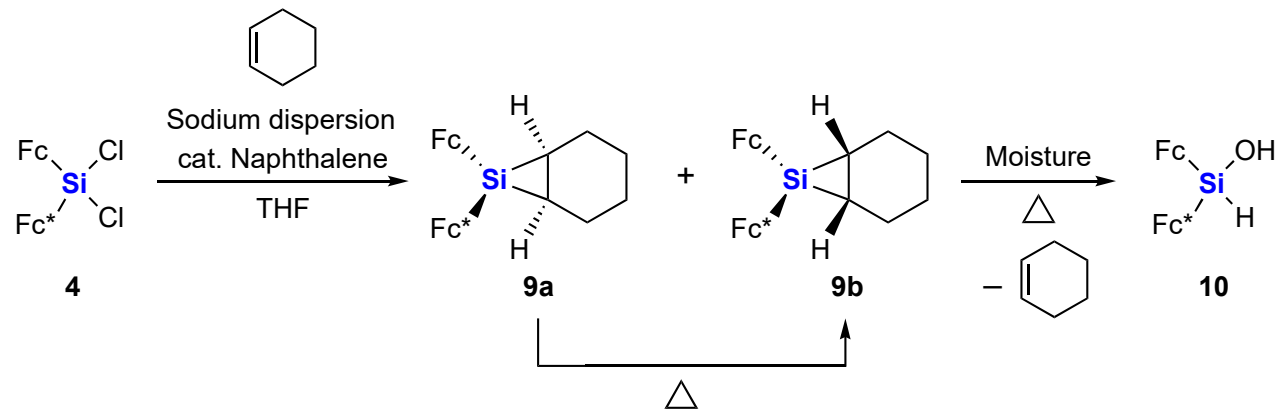

Scheme 3. Synthesis of bis(ferrocenyl)siliranes $9 a$ and $\mathbf{9 b}$.

The XRD structure of 9a (Figure 1) shows that the cyclohexane moiety of $\mathbf{9 a}$ is oriented toward the crowded space close to the $\mathrm{Fc}^{*}$ group; $9 \mathrm{~b}$ could thus potentially exhibit a more stable geometry wherein the cyclohexyl group is oriented toward the less bulky ferrocenyl moiety. Theoretical calculations at B3PW91-D3(BJ)/6-311G(3d) level of theory suggest that $9 \mathbf{b}$ is by $0.78 \mathrm{kcal} / \mathrm{mol}$ more stable than $9 \mathbf{a}$.

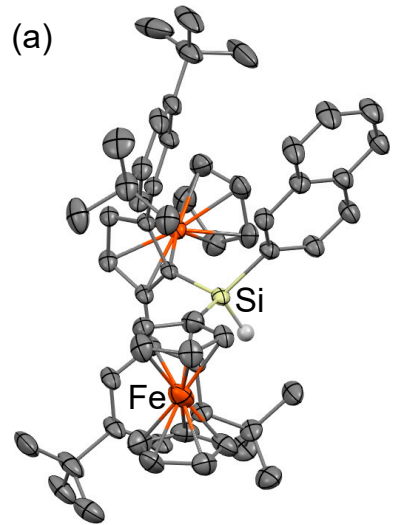

(b)

(c)

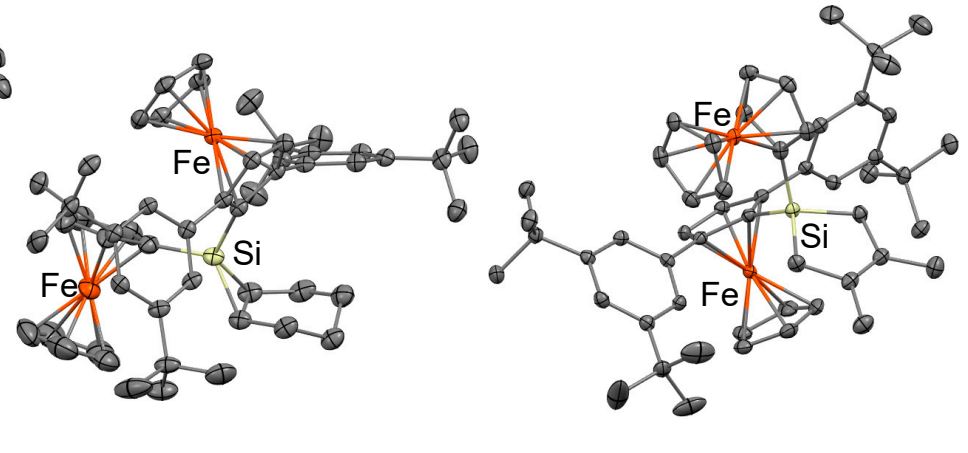

Figure 1. Molecular structures of (a) 5, (b) 9a, and (c) 14 with thermal ellipsoids at 50\% probability; hydrogen atoms other than that of the Si-H moiety are omitted for clarity.

As described above, heating of the cyclohexene solution of siliranes $9 \mathbf{a}$ and $9 \mathbf{b}$ at $75^{\circ} \mathrm{C}$ resulted in the conversion of $\mathbf{9 a}$ to $\mathbf{9 b}$ with concomitant formation of minor amounts of $\mathrm{Fc}^{*} \mathrm{FcSiH}(\mathrm{OH})(\mathbf{1 0})[46]$, suggesting the generation of silylene $\mathbf{1}$ in the equilibrium state. The formation of small amounts of $\mathbf{1 0}$ should most likely be interpreted in terms of a hydrolysis of silylene $\mathbf{1}$ generated by thermolysis of $\mathbf{9 a}$ and/or $\mathbf{9 b}$ due to the inevitable contamination with a small amount of moisture. Dissolving a mixture of $9 a$ and $\mathbf{9 b}(66: 34)$ in an excess amount of methanol at r.t. afforded $11(28 \%), \mathbf{1 2}(10 \%)$, and $13(15 \%)$ as shown in Scheme 4 [6,46]. The formation of $\mathbf{1 1}$ suggests the generation of silylene $\mathbf{1}$ at r.t. However, siliranes 9a and/or 9b would probably undergo alcoholysis with $\mathrm{MeOH}$ to give 12 and 13 under these conditions. Thus, siliranes $\mathbf{9 a}$ and $\mathbf{9 b}$ could be appropriate thermal precursors for silylene $\mathbf{1}$ on heating, although they are sensitive toward protic solvents. Conversely, heating of a mixture of $9 \mathbf{a}$ and $\mathbf{9 b}(25: 86)$ 
at $60{ }^{\circ} \mathrm{C}$ for $41 \mathrm{~h}$ in the presence of an excess of 2,3-dimethyl-1,3-butadiene afforded silolene 14 as the corresponding [1+4]cycloadduct of silylene 1 with 2,3-dimethyl-1,3-butadiene in 44\% isolated yield, suggesting that the thermolysis of both $\mathbf{9 a}$ and $\mathbf{9 b}$ affords silylene $\mathbf{1}$ at this temperature. Thus, it can be concluded that siliranes $\mathbf{9 a}$ and $\mathbf{9 b}$ could work as synthetic precursors for bis(ferrocenyl)silylene $\mathbf{1}$ in such pericyclic reactions.

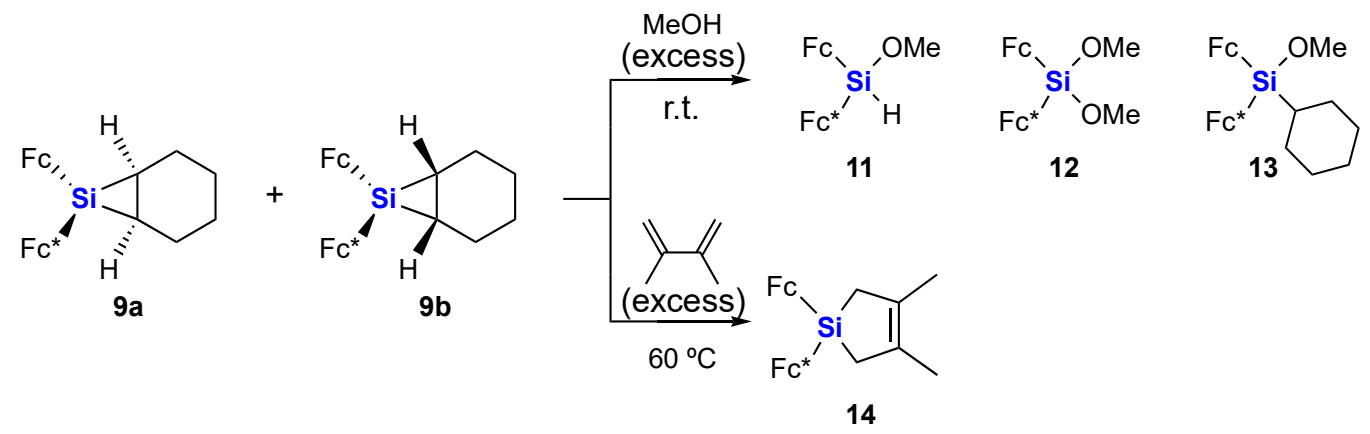

Scheme 4. Thermolysis of bis(ferrocenyl)siliranes $\mathbf{9 a}$ and $\mathbf{9 b}$ as well as trapping reactions of the transient silylene 1 .

Subsequently, we performed theoretical calculations on the dissociation energies of siliranes bearing several organic substituents at B3PW91-D3(BJ)/6-311G(3d) level of theory (Scheme 5). The dissociation energies of $9 \mathbf{a}$ and $\mathbf{9 b}$ are ca. $17 \mathrm{kcal} / \mathrm{mol}$, which are smaller than those of phenyl- and methyl-substituted siliranes $17(26.0 \mathrm{kcal} / \mathrm{mol})$ and $19(27.6 \mathrm{kcal} / \mathrm{mol})$. Considering the small dissociation energy of less bulky bis(ferrocenyl)silirane $15(14.0 \mathrm{kcal} / \mathrm{mol})$, the facile generation of silylene $\mathbf{1}$ from $\mathbf{9 a}$ and $\mathbf{9 b}$ under mild conditions could be explained, not by the steric hindrance due to the bulky Fc* group, but the electronic effect of the ferrocenyl groups. Even though the electronic perturbation from the ferrocenyl groups toward the silirane moiety of $\mathbf{9 a}$ and $\mathbf{9 b}$ remains unclear at present, the electron-donating properties of the ferrocenyl groups can be expected to lower the dissociation energy of the silirane skeleton.<smiles>FC(F)(F)[Si]1C2CCCC[C@H]2[C@H]1[18F]</smiles><smiles>FPC1CCCCC1</smiles><smiles>FC(F)[CH-][SiH2+]C(F)F</smiles>

$\Delta \mathrm{G}=16.7 \mathrm{kcal} / \mathrm{mol}$<smiles>O[C@@H]1CCC[C@@H]([Si](F)(F)F)[C@H]1F</smiles><smiles>F[C+](F)[CH-][SiH2]C(F)F</smiles>

$\Delta \mathrm{G}=17.2 \mathrm{kcal} / \mathrm{mol}$

$9 b$<smiles>FC[Si]1(F)C2CCCCC21</smiles>

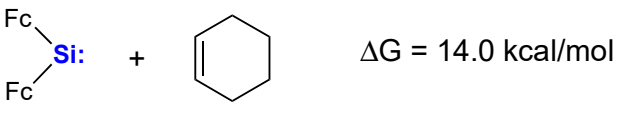

15

16<smiles>c1ccc([Si](c2ccccc2)(c2ccccc2)C2CCCCC2)cc1</smiles><smiles>C1=CCCCC1</smiles>

$\Delta \mathrm{G}=26.0 \mathrm{kcal} / \mathrm{mol}$

17<smiles>C[SiH2][CH-][SiH3]</smiles>

$\Delta \mathrm{G}=27.6 \mathrm{kcal} / \mathrm{mol}$<smiles>CCC1C2CCCC12[Si]</smiles><smiles>[CH]C</smiles>

Scheme 5. Calculated dissociation energies of siliranes $9 a$ and $9 b$, as well as 15,17 , and 19 to give the corresponding silylene and cyclohexene. 


\section{Materials and Methods}

\subsection{General Information}

All manipulations were carried out under an argon atmosphere using either Schlenk line techniques or glove boxes. All solvents were purified by standard methods. Trace amounts of water and oxygen remaining in the solvents were thoroughly removed by bulb-to-bulb distillation from potassium mirror prior to use. ${ }^{1} \mathrm{H},{ }^{13} \mathrm{C}$, and ${ }^{29} \mathrm{Si}-\mathrm{NMR}$ spectra were measured on a JEOL ECZ-500R $\left({ }^{1} \mathrm{H}: 500 \mathrm{MHz}\right.$, $\left.{ }^{13} \mathrm{C}: 126 \mathrm{MHz},{ }^{29} \mathrm{Si}: 99 \mathrm{MHz}\right)$ or on a Bruker AVANCE-400 spectrometer $\left({ }^{1} \mathrm{H}: 400 \mathrm{MHz},{ }^{13} \mathrm{C}: 101 \mathrm{MHz}\right.$, ${ }^{29} \mathrm{Si}$ : $\left.79 \mathrm{MHz}\right)$. Signals arising from residual $\mathrm{C}_{6} \mathrm{D}_{5} \mathrm{H}(7.15 \mathrm{ppm})$ in $\mathrm{C}_{6} \mathrm{D}_{6}$ or $\mathrm{CHCl}_{3}(7.26 \mathrm{ppm})$ in $\mathrm{CDCl}_{3}$ were used as the internal standards for the ${ }^{1} \mathrm{H}$ NMR spectra, while those of $\mathrm{C}_{6} \mathrm{D}_{6}(128.0 \mathrm{ppm})$ and $\mathrm{CDCl}_{3}$ (77.0 ppm) were used for the ${ }^{13} \mathrm{C}$ NMR spectra, and external $\mathrm{SiMe}_{4}(0.0 \mathrm{ppm})$ for the ${ }^{29} \mathrm{Si} \mathrm{NMR}$ spectra. High-resolution mass spectra (HRMS) were obtained from a JEOL JMS-T100LP (DART) or JMS-T100CS (APCI) mass spectrometer (DART). Gel permeation chromatography (GPC) was performed on an LC-6AD (Shimadzu Corp., Kyoto, Japan) equipped with JAIGEL-1H and 2H (Japan Analytical Industry Co., Ltd., Tokyo, Japan) columns using toluene as the eluent. All melting points were determined on a Büchi Melting Point Apparatus M-565 and are uncorrected. $\mathrm{Fc}^{*} \mathrm{Br}\left(\mathrm{Fc}^{*}=2,5-\left[3,5-(t \mathrm{Bu})_{2} \mathrm{C}_{6} \mathrm{H}_{3}\right]_{2}-1\right.$-ferrocenyl) was prepared according to literature procedures [40-42]. 1-Bromo-3,5-di-tert-butylbenzene was gifted by MANAC Inc., Tokyo, Japan.

\subsection{Syntheses and Reactions}

\subsubsection{Bis(ferrocenyl)dichlorosilane 4}

Ferrocene $(1.00 \mathrm{~g}, 5.38 \mathrm{mmol})$ was dissolved in THF $(4.0 \mathrm{~mL})$ and cooled to $0{ }^{\circ} \mathrm{C}$. During $30 \mathrm{~min}$, a pentane solution of $t$-BuLi $(3.6 \mathrm{~mL}, 1.6 \mathrm{M}$ in pentane, $5.76 \mathrm{mmol}$ ) was added dropwise. Then, hexane $(10 \mathrm{~mL})$ was added to the reaction mixture, and the solution was kept at $-78{ }^{\circ} \mathrm{C}$ for $15 \mathrm{~min}$. The resulting orange precipitate including ferrocenyl lithium was filtered off, and then washed with small portions of hexane. The orange precipitate was then dissolved in toluene $(4 \mathrm{~mL})$, and the solution was added to $\mathrm{SiCl}_{4}(884 \mathrm{mg}, 5.27 \mathrm{mmol})$. After stirring the mixture for $3 \mathrm{~h}$ at room temperature, the resulting inorganic salts were removed and the solvent of the filtrate was evaporated under reduced pressure to give ferrocenyltrichlorosilane $\mathbf{2}$ as an orange solid that was used for the subsequent reactions without further purification. An ether solution $(2 \mathrm{~mL})$ of $\mathrm{Fc} * \mathrm{Br}(635 \mathrm{mg}, 994 \mu \mathrm{mol})$ was treated with $n$-BuLi $(0.5 \mathrm{~mL}, 2.60 \mathrm{M}$ in hexane, $1.3 \mathrm{mmol})$ at $0^{\circ} \mathrm{C}$. After stirring for $6 \mathrm{~h}$ at room temperature, the solution of the resulting $\mathrm{FC}^{*}-\mathrm{Li}(3)$ was added to 2 at $0^{\circ} \mathrm{C}$. After stirring for $12 \mathrm{~h}$ at room temperature, the solution was filtered and the filtrate was evaporated under reduced pressure. The obtained orange solid was subjected to GPC (toluene) to give bis(ferrocenyl)dichlorosilane 4 (366 mg, $434 \mu \mathrm{mol}$, 44\%). 4: orange solid. Mp. 107-118 ${ }^{\circ} \mathrm{C} .{ }^{1} \mathrm{H}-\mathrm{NMR}\left(500 \mathrm{MHz}\right.$, benzene- $\left.d_{6}\right) \delta 7.70(\mathrm{~d}, J=1.7 \mathrm{~Hz}, 4 \mathrm{H})$, $7.49(\mathrm{t}, J=1.7 \mathrm{~Hz}, 2 \mathrm{H}), 4.44(\mathrm{~s}, 2 \mathrm{H}), 4.39(\mathrm{~s}, 5 \mathrm{H}), 4.12(\mathrm{~s}, 5 \mathrm{H}), 3.87(\mathrm{~s}, 4 \mathrm{H}), 1.42(\mathrm{~s}, 36 \mathrm{H}) ;{ }^{13} \mathrm{C}-\mathrm{NMR}$ $\left(126 \mathrm{MHz}\right.$, benzene- $\left.d_{6}\right) \delta 150.0,137.2,128.3,128.1,127.9,126.1,121.3,99.7,75.1,74.6,72.0,71.2,69.8$, 69.2, 64.5, 35.1, 31.8; ${ }^{29} \mathrm{Si}-\mathrm{NMR}\left(79 \mathrm{MHz}\right.$, benzene- $\left.d_{6}\right) \delta 11.9$. HRMS (APCI), $m / z$ : Found: 844.23901 $\left(\left[\mathrm{M}^{+}\right]\right)$, Calcd. for $\mathrm{C}_{48} \mathrm{H}_{58} \mathrm{Cl}_{2} \mathrm{Fe}_{2} \mathrm{Si}\left(\left[\mathrm{M}^{+}\right]\right): 844.23837$.

\subsubsection{Bis(ferrocenyl)naphthylsilane 5}

A THF solution of LiNaph $(0.2 \mathrm{~mL}, 1.1 \mathrm{M}$ THF solution, $0.22 \mathrm{mmol})$ was added dropwise to a THF solution $(0.2 \mathrm{~mL})$ of bis(ferrocenyl)dichlorosilane $4(47.7 \mathrm{mg}, 56.5 \mu \mathrm{mol})$ at $-78^{\circ} \mathrm{C}$. After stirring for $24 \mathrm{~h}$ at room temperature, the solvent was removed under reduced pressure, and the residue was dissolved in benzene. The resulting inorganic salts were removed by filtration and the filtrate was evaporated under reduced pressure to give 5 as an orange solid (quant. as judged by ${ }^{1} \mathrm{H}-\mathrm{NMR}$ spectrum). The orange solid of 5 was purified by GPC (toluene) to give 5 in pure form (15.1 mg, $16.7 \mu \mathrm{mol}, 30 \%)$. 5: orange solid. Mp. 195-200 ${ }^{\circ} \mathrm{C} .{ }^{1} \mathrm{H}-\mathrm{NMR}\left(500 \mathrm{MHz}\right.$, benzene- $\left.d_{6}\right) \delta 8.20(\mathrm{~s}, 1 \mathrm{H}), 7.90$ $(\mathrm{d}, J=8.0 \mathrm{~Hz}, 1 \mathrm{H}), 7.74(\mathrm{~d}, J=1.7 \mathrm{~Hz}, 2 \mathrm{H}), 7.66(\mathrm{~d}, J=8.0 \mathrm{~Hz}, 1 \mathrm{H}), 7.63-7.64(\mathrm{~m}, 1 \mathrm{H}), 7.61(\mathrm{~d}, J=1.7 \mathrm{~Hz}$, 
$2 \mathrm{H}), 7.59(\mathrm{q}, J=2.1 \mathrm{~Hz}, 1 \mathrm{H}), 7.42(\mathrm{t}, J=1.7 \mathrm{~Hz}, 2 \mathrm{H}), 7.24-7.27(\mathrm{~m}, 2 \mathrm{H}), 6.21(\mathrm{~s}, 1 \mathrm{H}), 4.65(\mathrm{~d}, J=1.1 \mathrm{~Hz}$, 2H), $4.34(\mathrm{~s}, 5 \mathrm{H}), 4.16(\mathrm{~d}, J=1.1 \mathrm{~Hz}, 1 \mathrm{H}), 4.05(\mathrm{~s}, 1 \mathrm{H}), 3.99(\mathrm{~s}, 1 \mathrm{H}), 3.88(\mathrm{~s}, 5 \mathrm{H}), 3.82(\mathrm{~d}, J=1.1 \mathrm{~Hz}$, $1 \mathrm{H}), 1.37(\mathrm{~s}, 18 \mathrm{H}), 1.20(\mathrm{~s}, 18 \mathrm{H}),{ }^{29} \mathrm{Si}-\mathrm{NMR}\left(99 \mathrm{MHz}\right.$, benzene- $\left.d_{6}\right) \delta-19.5$. HRMS (APCI), $m / z$ : Found: $902.36587\left(\left[\mathrm{M}^{+}\right]\right)$, Calcd. for $\mathrm{C}_{58} \mathrm{H}_{66} \mathrm{Fe}_{2} \mathrm{Si}\left(\left[\mathrm{M}^{+}\right]\right): 902.36326$.

\subsubsection{Siliranes $9 a$ and $9 \mathbf{b}$}

A mixture of sodium (dispersion in mineral oil, $7.2 \mathrm{mg}, 313 \mu \mathrm{mol})$, naphthalene $(25.5 \mathrm{mg}, 199 \mu \mathrm{mol})$, and cyclohexene $(0.2 \mathrm{~mL}, 1.85 \mathrm{mmol})$ was added to a THF/Et ${ }_{2} \mathrm{O}(1: 1,0.4 \mathrm{~mL})$ solution of $4(92.3 \mathrm{mg}$, $109 \mu \mathrm{mol})$. After stirring for $12 \mathrm{~h}$ at room temperature, the solvent and residual cyclohexene were removed under reduced pressure, before the residue was dissolved in cyclohexane. After filtration, the solvent of the filtrate was evaporated under reduced pressure. The obtained orange solid was subjected to GPC (toluene) to give a mixture of $\mathbf{9 a}$ and $\mathbf{9 b}$ (66:34 ratio as judged by the ${ }^{1} \mathrm{H}-\mathrm{NMR}$ spectrum, $80.5 \mathrm{mg}$, $94.0 \mu \mathrm{mol}$, total yield: $86 \%$ ). Continuous recrystallization of the mixture from hexane afforded a few crystals of $9 a$, which could be isolated by the filtration. After evaporating the solvent of the filtrate, the residue was heated at $120^{\circ} \mathrm{C}$ for a few hours under the reduced pressure. The following recrystallization of the resulting solids from pentane afforded a few crystals of $9 \mathbf{b}$ in pure form. 9a: orange solid. Mp. $174.1{ }^{\circ} \mathrm{C}$ (decomp). ${ }^{1} \mathrm{H}-\mathrm{NMR}\left(400 \mathrm{MHz}\right.$, benzene- $\left.d_{6}\right) ; \delta 7.93(\mathrm{~d}, J=1.9 \mathrm{~Hz}$, $4 \mathrm{H}), 7.53(\mathrm{t}, J=1.9 \mathrm{~Hz}, 2 \mathrm{H}), 4.75(\mathrm{~s}, 2 \mathrm{H}), 4.24(\mathrm{br} \mathrm{s}, 2 \mathrm{H}), 4.11(\mathrm{t}, J=1.9 \mathrm{~Hz}, 2 \mathrm{H}), 4.03(\mathrm{~s}, 5 \mathrm{H}), 3.86(\mathrm{br} \mathrm{s}$, 5H), 1.99 (br s, 2H), 1.73 (br s, 2H), 1.49 (s, 36H), 1.26-1.27 (br, 6H); ${ }^{13} \mathrm{C}-\mathrm{NMR}$ (101 MHz, benzene- $\left.d_{6}\right) \delta$ 150.16, 139.86, 125.32, 120.40, 96.84, 75.04, 73.10, 72.66, 70.79, 69.16, 68.96, 66.73, 35.21, 31.91, 24.95, 22.66, 11.96; ${ }^{29} \mathrm{Si}-\mathrm{NMR}\left(79 \mathrm{MHz}\right.$, benzene- $\left.d_{6}\right) \delta$-67.6. HRMS (DART), $m / z$ : Found: 856.38901 ([M $\left.\left.{ }^{+}\right]\right)$, Calcd. for $\mathrm{C}_{54} \mathrm{H}_{68} \mathrm{Fe}_{2} \mathrm{Si}\left(\left[\mathrm{M}^{+}\right]\right)$: 856.38826. 9b: orange solid. Mp. $151.2{ }^{\circ} \mathrm{C}$ (decomp). $\delta 7.94(\mathrm{~d}, J=1.8 \mathrm{~Hz}$, $4 \mathrm{H}), 7.52(\mathrm{t}, J=1.8 \mathrm{~Hz}, 2 \mathrm{H}), 4.73(\mathrm{~s}, 2 \mathrm{H}), 4.16(\mathrm{~s}, 5 \mathrm{H}), 4.10(\mathrm{t}, J=1.8 \mathrm{~Hz}, 2 \mathrm{H}), 3.99(\mathrm{t}, J=1.8 \mathrm{~Hz}, 2 \mathrm{H})$, $3.82(\mathrm{~s}, 5 \mathrm{H}), 2.06$ (br s, 2H), 1.73-1.79 (br m, 4H), 1.52 (br s, 4H), $1.43(\mathrm{~s}, 36 \mathrm{H}) ;{ }^{13} \mathrm{C}-\mathrm{NMR}(101 \mathrm{MHz}$, benzene- $\left.d_{6}\right) \delta 150.25,139.50,125.27,121.23,97.72,75.99,73.13,71.95,71.12,69.16,68.23,64.17,35.13$, $31.93,23.92,21.63,14.47 ;{ }^{29} \mathrm{Si}-\mathrm{NMR}\left(79 \mathrm{MHz}\right.$, benzene- $\left.d_{6}\right) \delta-69.8$. Continuous recrystallizations of a mixture of $9 \mathbf{a}$ and $\mathbf{9 b}$ from hexanes afforded a very small amount of single crystals of $\mathbf{9 a}$ in pure form. Spectroscopic and XRD analyses of the single crystals thus obtained enabled us to identify 9a. Silirane $\mathbf{9 b}$ was identified based on the spectral data including ${ }^{29} \mathrm{Si}$ NMR data, which was similar to those of $\mathbf{9 a}$.

\subsubsection{Thermolysis of Siliranes $\mathbf{9 a}$ and $\mathbf{9 b}$ in Cyclohexene}

Cyclohexene $\left(0.7 \mathrm{~mL}\right.$ ) was added to a mixture of $9 \mathbf{a}$ and $\mathbf{9 b}$ (94:6 ratio as judged by the ${ }^{1} \mathrm{H}$ NMR spectrum). After heating at $75{ }^{\circ} \mathrm{C}$ for $30 \mathrm{~min}$, the residual cyclohexene was removed under reduced pressure. The ${ }^{1} \mathrm{H}$ NMR spectrum of the residue in $\mathrm{C}_{6} \mathrm{D}_{6}$ showed the signals for $9 \mathbf{a}$ and $\mathbf{9} \mathbf{b}$ (45:55 ratio).

\subsubsection{Thermolysis of Siliranes $\mathbf{9 a}$ and $\mathbf{9 b}$ in the Solid State}

A mixture of the orange solids of $9 \mathbf{a}$ and $9 \mathbf{b}$ (74:26 ratio as judged by the ${ }^{1} \mathrm{H}-\mathrm{NMR}$ spectrum) was heated at $120^{\circ} \mathrm{C}$ for $30 \mathrm{~min}$ under evacuation in an NMR tube $(5 \mathrm{~mm}$ diameter) equipped with a J-Young@ tap. The ${ }^{1} \mathrm{H}-\mathrm{NMR}$ spectrum of the residue in $\mathrm{C}_{6} \mathrm{D}_{6}$ showed the signals for $9 \mathbf{a}$ and $\mathbf{9 b}$ (45:55 ratio).

\subsubsection{Reaction of Siliranes $\mathbf{9 a}$ and $\mathbf{9 b}$ with Methanol}

$\mathrm{MeOH}(0.40 \mathrm{~mL})$ was added to a mixture of siliranes $9 \mathbf{a}$ and $9 \mathbf{b}(66: 34,24.0 \mathrm{mg}, 28.0 \mu \mathrm{mol})$ at room temperature. After stirring for $72 \mathrm{~h}$ at room temperature, the solvent was removed under reduced pressure. The obtained residue was purified by column chromatography on silica gel (hexane/benzene $=4: 1)$ to give $\mathbf{1 1}(6.3 \mathrm{mg}, 7.8 \mu \mathrm{mol}, 28 \%), \mathbf{1 2}(2.3 \mathrm{mg}, 2.8 \mu \mathrm{mol}, 10 \%)$ and $\mathbf{1 3}(3.8 \mathrm{mg}, 4.3 \mu \mathrm{mol}$, 15\%) 11: orange solid. Mp. $161-164{ }^{\circ} \mathrm{C} .{ }^{1} \mathrm{H}-\mathrm{NMR}\left(400 \mathrm{MHz}\right.$, benzene- $\left.d_{6}\right) \delta 7.98(\mathrm{~d}, J=1.8 \mathrm{~Hz}, 2 \mathrm{H})$, $7.82(\mathrm{~d}, J=1.8 \mathrm{~Hz}, 2 \mathrm{H}), 7.51(\mathrm{q}, J=1.8 \mathrm{~Hz}, 2 \mathrm{H}), 5.59(\mathrm{~s}, 1 \mathrm{H}), 4.80(\mathrm{~d}, J=2.3 \mathrm{~Hz}, 1 \mathrm{H}), 4.74(\mathrm{~d}, J=2.3 \mathrm{~Hz}$, $1 \mathrm{H}), 4.28(\mathrm{~s}, 5 \mathrm{H}), 4.00(\mathrm{td}, J=2.3,1.1 \mathrm{~Hz}, 1 \mathrm{H}), 3.95(\mathrm{td}, J=2.3,1.1 \mathrm{~Hz}, 1 \mathrm{H}), 3.90-3.91(\mathrm{~m}, 1 \mathrm{H}), 3.85$ $(\mathrm{s}, 5 \mathrm{H}), 3.62(\mathrm{~s}, 3 \mathrm{H}), 3.23(\mathrm{t}, J=1.1 \mathrm{~Hz}, 1 \mathrm{H}), 1.44(\mathrm{~d}, \mathrm{~J}=1.3 \mathrm{~Hz}, 36 \mathrm{H})$. HRMS (DART), $m / z$ : Found: 806.32643 ([M $\left.\left.{ }^{+}\right]\right)$, Calcd. for $\mathrm{C}_{49} \mathrm{H}_{62} \mathrm{Fe}_{2} \mathrm{OSi}\left(\left[\mathrm{M}^{+}\right]\right)$: 806.32688. 12: orange solid. Mp. $67-71^{\circ} \mathrm{C} .{ }^{1} \mathrm{H}-\mathrm{NMR}$ 
(400 MHz, benzene- $\left.d_{6}\right) \delta 7.84(\mathrm{~d}, J=1.8 \mathrm{~Hz}, 4 \mathrm{H}), 7.51(\mathrm{t}, J=1.8 \mathrm{~Hz}, 2 \mathrm{H}), 4.59(\mathrm{~s}, 2 \mathrm{H}), 4.34(\mathrm{~s}, 5 \mathrm{H})$, $4.03(\mathrm{t}, J=1.8 \mathrm{~Hz}, 2 \mathrm{H}), 4.01(\mathrm{~s}, 5 \mathrm{H}), 3.82(\mathrm{t}, J=1.8 \mathrm{~Hz}, 2 \mathrm{H}), 3.38(\mathrm{~s}, 6 \mathrm{H}), 1.46(\mathrm{~s}, 36 \mathrm{H})$. HRMS (DART), $m / z$ : Found: $836.33713\left(\left[\mathrm{M}^{+}\right]\right)$, Calcd. for $\mathrm{C}_{50} \mathrm{H}_{64} \mathrm{Fe}_{2} \mathrm{O}_{2} \mathrm{Si}\left(\left[\mathrm{M}^{+}\right]\right)$: 836.33744. 13: orange solid. Mp. 98-103 ${ }^{\circ} \mathrm{C} .{ }^{1} \mathrm{H}-\mathrm{NMR}\left(400 \mathrm{MHz}\right.$, benzene- $\left.d_{6}\right) \delta 7.73(\mathrm{~d}, J=1.8 \mathrm{~Hz}, 2 \mathrm{H}), 7.65(\mathrm{~d}, J=1.8 \mathrm{~Hz}, 2 \mathrm{H}), 7.47-7.48$ $(\mathrm{m}, 2 \mathrm{H}), 4.54(\mathrm{~d}, J=2.3 \mathrm{~Hz}, 1 \mathrm{H}), 4.52(\mathrm{~d}, J=2.3 \mathrm{~Hz}, 1 \mathrm{H}), 4.27(\mathrm{~s}, 5 \mathrm{H}), 4.08-4.10(\mathrm{~m}, 3 \mathrm{H}), 4.01(\mathrm{~s}, 5 \mathrm{H}), 3.94$ (s, 1H), 3.29 (s, 3H), 2.27 (br d, $J=13.8 \mathrm{~Hz}, 1 \mathrm{H}), 2.16($ br d, $J=13.8 \mathrm{~Hz}, 1 \mathrm{H}), 1.82($ br d, $J=13.8 \mathrm{~Hz}, 1 \mathrm{H})$, 1.75 (br d, $J=13.8 \mathrm{~Hz}, 2 \mathrm{H}), 1.55-1.60$ (br, 1H), 1.45 (d, $J=1.8 \mathrm{~Hz}, 36 \mathrm{H}), 1.40-1.41$ (br, 1H), $1.39-1.39$ (br,

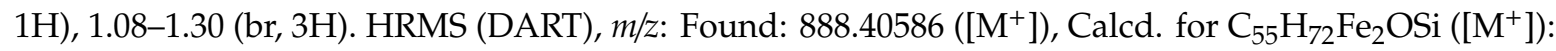
888.40513.

\subsubsection{Reaction of Siliranes $9 a$ and $9 \mathbf{b}$ with 2,3-Dimethyl-1,3-butadiene}

2,3-Dimethyl-1,3-butadiene $(0.50 \mathrm{~mL}, 4.40 \mathrm{mmol})$ was added to a mixture of $9 \mathbf{a}$ and $9 \mathbf{b}$ (25:86 ratio, $5.7 \mathrm{mg}$, $6.7 \mu \mathrm{mol})$. After stirring for $41 \mathrm{~h}$ at $60{ }^{\circ} \mathrm{C}$, the residual 2,3-dimethyl-1,3-butadiene was removed under reduced pressure to give 14 (quant. as judged by the ${ }^{1} \mathrm{H}-\mathrm{NMR}$ spectrum). The obtained orange solid of 14 was purified by column chromatography on silica gel (hexane/benzene $=4: 1$ ) to give 14 in pure form (2.5 mg, $2.9 \mu \mathrm{mol}, 44 \%$ ). 14: orange solid. Mp. $242{ }^{\circ} \mathrm{C}$ (decomp). ${ }^{1} \mathrm{H}-\mathrm{NMR}\left(400 \mathrm{MHz}\right.$, benzene- $\left.d_{6}\right)$ $\delta 7.70(\mathrm{~d}, J=1.8 \mathrm{~Hz}, 4 \mathrm{H}), 7.50(\mathrm{t}, J=1.8 \mathrm{~Hz}, 2 \mathrm{H}), 4.53(\mathrm{~s}, 2 \mathrm{H}), 4.36(\mathrm{~s}, 5 \mathrm{H}), 4.17(\mathrm{t}, J=1.8 \mathrm{~Hz}, 2 \mathrm{H}), 4.06$ $(\mathrm{t}, J=1.8 \mathrm{~Hz}, 2 \mathrm{H}), 3.86(\mathrm{~s}, 5 \mathrm{H}), 2.02(\mathrm{~d}, J=17.6 \mathrm{~Hz}, 2 \mathrm{H}), 1.77(\mathrm{~m}, 8 \mathrm{H}), 1.40(\mathrm{~s}, 36 \mathrm{H}){ }^{29} \mathrm{Si}-\mathrm{NMR}(79 \mathrm{MHz}$, benzene- $\left.d_{6}\right) \delta$ 2.15. HRMS (DART), $m / z$ : Found: $856.38994\left(\left[\mathrm{M}^{+}\right]\right)$, Calcd. for $\mathrm{C}_{54} \mathrm{H}_{68} \mathrm{Fe}_{2} \mathrm{Si}: 856.38826$.

\subsubsection{Characterization of $\mathrm{FC}^{*}(\mathrm{Fc}) \mathrm{Si}(\mathrm{OH})_{2}$}

Orange solid. Mp. $144-151{ }^{\circ} \mathrm{C} .{ }^{1} \mathrm{H}-\mathrm{NMR}\left(400 \mathrm{MHz}\right.$, benzene- $\left.d_{6}\right) \delta 7.84(\mathrm{~d}, J=1.9 \mathrm{~Hz}, 4 \mathrm{H}), 7.50$ $(\mathrm{t}, J=1.9 \mathrm{~Hz}, 2 \mathrm{H}), 4.57(\mathrm{~s}, 2 \mathrm{H}), 4.34(\mathrm{~s}, 5 \mathrm{H}), 3.99(\mathrm{q}, J=1.9 \mathrm{~Hz}, 7 \mathrm{H}), 3.85(\mathrm{t}, J=1.9 \mathrm{~Hz}, 2 \mathrm{H}), 2.68(\mathrm{~s}, 2 \mathrm{H}), 1.40$ (s, 36H). HRMS (APCI), m/z: Found: 808.31153 ([M+]), Calcd. for $\mathrm{C}_{48} \mathrm{H}_{60} \mathrm{Fe}_{2} \mathrm{O}_{2} \mathrm{Si}\left(\left[\mathrm{M}^{+}\right]\right):$808.30614.

\subsection{Computational Methods}

The level of theory and the basis sets used for the structural optimization are given in the main text. Frequency calculations confirmed minimum energies for all optimized structures. All calculations were carried out on the Gaussian 16 (Revision C.01) program package [53]. Computational time was generously provided by the Supercomputer Laboratory in the Institute for Chemical Research of Kyoto University.

\subsection{X-ray Crystallographic Analysis}

Single crystals of $\mathbf{5}, \mathbf{9 a}, \mathbf{1 0}, \mathbf{1 1}, \mathbf{1 3}, \mathbf{1 4}$, and $\mathrm{Fc}^{*} \mathrm{FcSi}(\mathrm{OH})_{2}$ were obtained by recrystallization from $\mathrm{Et}_{2} \mathrm{O}\left(\mathbf{5}, \mathbf{9 a}, \mathbf{1 0}, \mathbf{1 4}, \mathrm{Fc}^{*} \mathrm{FcSi}(\mathrm{OH})_{2}\right)$ at room temperature or from $\mathrm{Et}_{2} \mathrm{O} / \mathrm{MeOH}(\mathbf{1 1}, \mathbf{1 3})$ at $-30^{\circ} \mathrm{C}$. Intensity data for 9a were collected on a RIGAKU Saturn70 CCD(system) with VariMax Mo Optics using Mo-K $\alpha$ radiation $(\lambda=0.71073 \AA$ ), while those for others were collected at the BL02B1 beamline of SPring-8 (2018A1167, 2018B1668, 2018B1179, 2019A1057, 2019A1677, 2019B1129, 2019B1784, 2020A1056, 2020A1644, 2020A1650, 2020A0834) on a PILATUS3 X CdTe 1M camera using synchrotron radiation $(\lambda=0.4148 \AA)$. The structures were solved using SHELXT-2014 and refined by a full-matrix least-squares method on $F^{2}$ for all reflections using the programs of SHELXL-2016 [54,55]. All non-hydrogen atoms were refined anisotropically, and the positions of all hydrogen atoms were calculated geometrically and refined as riding models. Supplementary crystallographic data were deposited at the Cambridge Crystallographic Data Centre (CCDC) under deposition numbers CCDC-2044338-2044344 and can be obtained free of charge from via www.ccdc.cam.ac.uk/data_request.cif.

Crystallographic data for 5 (CCDC-2044338): $\mathrm{C}_{58} \mathrm{H}_{66} \mathrm{Fe}_{2} \mathrm{Si}, \quad \mathrm{FW}$ 902.89, crystal size $0.01 \times 0.01 \times 0.01 \mathrm{~mm}^{3}$, temperature $-180{ }^{\circ} \mathrm{C}, \lambda=0.4148 \AA$, triclinic, space group $P-1(\# 2)$, $a=12.072(5) \AA, b=12.297(5) \AA, c=16.770(7) \AA, \alpha=84.253(5)^{\circ}, \beta=80.861(5)^{\circ}, \gamma=89.400(5)^{\circ}$, $V=2445.4(18) \AA^{3}, Z=2, D_{\text {calcd }}=1.226 \mathrm{~g} \mathrm{~cm}^{-3}, \mu=0.158 \mathrm{~mm}^{-1}, \theta_{\max }=15.729^{\circ}, 57,864$ reflections measured, 11,360 independent reflections $\left(R_{\text {int }}=0.0717\right), 692$ parameters refined, GOF $=1.029$, 
completeness $=99.4 \%, R_{1}[I>2 \sigma(I)]=0.0651, \mathrm{w} R_{2}$ (all data) $=0.1685$, largest diff. peak and hole 1.262 and -1.498 e $\AA^{-3}$. 9a (CCDC-2044339): $\mathrm{C}_{54} \mathrm{H}_{68} \mathrm{Fe}_{2} \mathrm{Si}$, FW 856.87, crystal size $0.15 \times 0.10 \times 0.08 \mathrm{~mm}^{3}$, temperature $-170{ }^{\circ} \mathrm{C}, \lambda=0.71073 \AA$, triclinic, space group $P-1$ (\#2), $a=10.1310(3) \AA, b=15.7957(4) \AA$, $c=16.3047(4) \AA, \alpha=67.199(2)^{\circ}, \beta=76.969(2)^{\circ}, \gamma=76.374(2)^{\circ}, V=2311.22(11) \AA^{3}, Z=2$, $D_{\text {calcd }}=1.231 \mathrm{~g} \mathrm{~cm}^{-3}, \mu=0.688 \mathrm{~mm}^{-1}, \theta_{\max }=30.835^{\circ}, 41513$ reflections measured, 9056 independent reflections $\left(R_{\mathrm{int}}=0.0429\right)$, 551 parameters refined, $\mathrm{GOF}=1.045$, completeness $=99.6 \%$, $R_{1}[I>2 \sigma(I)]=0.0540, \mathrm{w} R_{2}$ (all data) $=0.1443$, largest diff. peak and hole 1.694 and -1.089 e $\AA^{-3}$. 10 (CCDC-2044340): $\mathrm{C}_{48} \mathrm{H}_{60} \mathrm{Fe}_{2} \mathrm{OSi}$, FW 792.75, crystal size $0.02 \times 0.01 \times 0.01 \mathrm{~mm}^{3}$, temperature $-180{ }^{\circ} \mathrm{C}$, $\lambda=0.4148 \AA$, triclinic, space group $P-1(\# 2), a=11.551(5) \AA, b=13.356(6) \AA, c=15.732(7) \AA$, $\alpha=104.761(6)^{\circ}, \beta=108.360(6)^{\circ}, \gamma=100.704(6)^{\circ}, V=2131.9(17) \AA^{3}, Z=2, D_{\text {calcd }}=1.235 \mathrm{~g} \mathrm{~cm}^{-3}$, $\mu=0.177 \mathrm{~mm}^{-1}, \theta_{\max }=15.694^{\circ}, 50,376$ reflections measured, 9876 independent reflections $\left(R_{\text {int }}=0.0869\right)$, 491 parameters refined, $\mathrm{GOF}=1.016$, completeness $=99.6 \%, R_{1}[I>2 \sigma(I)]=0.0449, \mathrm{w} R_{2}$ (all data) $=0.1211$, largest diff. peak and hole 0.549 and -0.861 e $\AA^{-3} .11$ (CCDC-2044341): $\mathrm{C}_{49} \mathrm{H}_{62} \mathrm{Fe}_{2} \mathrm{OSi}$, FW 806.78, crystal size $0.01 \times 0.01 \times 0.01 \mathrm{~mm}^{3}$, temperature $-180^{\circ} \mathrm{C}, \lambda=0.4148 \AA$, triclinic, space group $P-1$ (\#2), $a=9.748(8) \AA, b=12.421(10) \AA, c=18.807(15) \AA, \alpha=78.213(8)^{\circ}, \beta=78.790(11)^{\circ}, \gamma=85.260(9)^{\circ}$, $V=2185(3) \AA^{3}, Z=2, D_{\text {calcd }}=1.227 \mathrm{~g} \mathrm{~cm}^{-3}, \mu=0.173 \mathrm{~mm}^{-1}, \theta_{\max }=15.765^{\circ}, 52,665$ reflections measured, 9471 independent reflections $\left(R_{\text {int }}=0.0912\right), 553$ parameters refined, GOF $=1.040$, completeness $=92.1 \%$, $R_{1}[I>2 \sigma(I)]=0.0879, \mathrm{w} R_{2}$ (all data) $=0.2863$, largest diff. peak and hole 1.659 and -1.131 e $\AA^{-3}$. 13 (CCDC-2044342): $\mathrm{C}_{59} \mathrm{H}_{82} \mathrm{Fe}_{2} \mathrm{O}_{2} \mathrm{Si}$, FW 963.04, crystal size $0.01 \times 0.01 \times 0.01 \mathrm{~mm}^{3}$, temperature $-180{ }^{\circ} \mathrm{C}, \lambda=0.4148 \AA$, triclinic, space group $P-1(\# 2), a=10.29(5) \AA, b=15.09(7) \AA, c=16.60(8) \AA$, $\alpha=104.05(4)^{\circ}, \beta=96.46(5)^{\circ}, \gamma=92.32(5)^{\circ}, V=2478(21) \AA^{3}, Z=2, D_{\text {calcd }}=1.291 \mathrm{~g} \mathrm{~cm}^{-3}, \mu=0.158$ $\mathrm{mm}^{-1}, \theta_{\max }=9.863^{\circ}, 14,683$ reflections measured, 2889 independent reflections $\left(R_{\text {int }}=0.2584\right), 577$ parameters refined, $\mathrm{GOF}=1.049$, completeness $=98.3 \%, R_{1}[I>2 \sigma(I)]=0.1088, \mathrm{w} R_{2}$ (all data) $=0.3010$, largest diff. peak and hole 0.320 and -0.426 e $\AA^{-3}$. Only preliminary data have been obtained, since the single crystals of this compound have been obtained only in very poor quality despite several attempts of careful recrystallization probably due to the partial hydrolysis of the Si-OMe moiety. 14 (CCDC-2044343): $\mathrm{C}_{54} \mathrm{H}_{68} \mathrm{Fe}_{2} \mathrm{Si}$, FW 856.87, crystal size $0.01 \times 0.01 \times 0.01 \mathrm{~mm}^{3}$, temperature $-180{ }^{\circ} \mathrm{C}$, $\lambda=0.4148 \AA$, triclinic, space group $P-1(\# 2), a=10.546(10) \AA, b=12.346(12) \AA, c=18.329(19) \AA$, $\alpha=92.52(2)^{\circ}, \beta=97.949(12)^{\circ}, \gamma=99.949(16)^{\circ}, V=2322(4) \AA^{3}, Z=2, D_{\text {calcd }}=1.225 \mathrm{~g} \mathrm{~cm}^{-3}, \mu=0.164 \mathrm{~mm}^{-1}$, $\theta_{\max }=13.916^{\circ}, 37,917$ reflections measured, 7520 independent reflections $\left(R_{\text {int }}=0.0674\right), 529$ parameters refined, $\mathrm{GOF}=1.031$, completeness $=99.3 \%, R_{1}[I>2 \sigma(I)]=0.0437, \mathrm{w} R_{2}$ (all data) $=0.1260$, largest diff. peak and hole 0.771 and -0.648 e $\AA^{-3}$. $\mathrm{Fc}^{*} \mathrm{FcSi}(\mathrm{OH})_{2}(\mathrm{CCDC}-2044344): \mathrm{C}_{48} \mathrm{H}_{60} \mathrm{Fe}_{2} \mathrm{O}_{2} \mathrm{Si}, \mathrm{FW}$ 808.75, crystal size $0.25 \times 0.20 \times 0.10 \mathrm{~mm}^{3}$, temperature $-170{ }^{\circ} \mathrm{C}, \lambda=0.71075 \AA$, triclinic, space group $P-1(\# 2)$, $a=11.4879(2) \AA, b=13.2748(1) \AA, c=15.6366(2) \AA, \alpha=104.3460(1)^{\circ}, \beta=108.2530(1)^{\circ}, \gamma=101.1560(1)^{\circ}$, $V=2096.58(5) \AA^{3}, Z=2, D_{\text {calcd }}=1.281 \mathrm{~g} \mathrm{~cm}^{-3}, \mu=0.758 \mathrm{~mm}^{-1}, \theta_{\max }=26.999^{\circ}, 39,810$ reflections measured, 9082 independent reflections $\left(R_{\text {int }}=0.0365\right), 718$ parameters refined, GOF $=1.127$, completeness $=99.2 \%$, $R_{1}[I>2 \sigma(I)]=0.0365, \mathrm{w} R_{2}$ (all data) $=0.0826$, largest diff. peak and hole 0.395 and $-0.437 \mathrm{e} \AA^{-3}$.

\section{Conclusions}

Bis(ferrocenyl)siliranes $\mathbf{9 a}$ and $\mathbf{9 b}$ were prepared by the reduction of the corresponding dichlorosilane with lithium naphthalenide in the presence of an excess of cyclohexene. Siliranes $9 \mathbf{a}$ and $\mathbf{9 b}$ are appropriate precursors for bis(ferrocenyl)silylenes upon heating under mild conditions, i.e., they can be considered as bottleable synthetic precursors for silylenes. Further investigations into the creation of redox-active organosilicon compounds that bear ferrocenyl moieties by using siliranes 9a and $\mathbf{b}$ as silylene precursors are currently in progress in our laboratory.

Author Contributions: Conceptualization, Y.P. and T.S.; resources and funding acquisition, T.S. and S.A.; XRD analyses, T.S. and S.M.; theoretical calculations (Gaussian 16). T.S.; experiments, Y.P.; writing-original draft preparation, Y.P.; review and editing, T.S.; project administration, T.S. All authors have read and agreed to the published version of the manuscript. 
Funding: This research was funded by JSPS KAKENHI grants 19H02705 and 19K22188 from MEXT (Japan), the Collaborative Research Program of the Institute for Chemical Research at Kyoto University (2018-22), TOBE MAKI Scholarship Foundation (20-JA-014), Mitsubishi Gas Chemical, and JST CREST grant JPMJCR19R4.

Acknowledgments: We acknowledge the generous assistance of the Research Equipment Sharing Center at Nagoya City University, Spring-8 (BL02B1: 2018A1167, 2018B1668, 2018B1179, 2019A1057, 2019A1677, 2019B1129, 2019B1784, 2020A1056, 2020A1644, 2020A1650, 2020A0834), and the Supercomputer Laboratory in the Institute for Chemical Research of Kyoto University for their technical support as well as the resources used. We would like to thank Toshiaki Noda and Hideko Natsume (Nagoya University) for the expert manufacturing of custom-tailored glassware. Moreover, we would like to express our appreciation to MANAC Inc. for a kind gift of 1-bromo-3,5-di-tert-butylbenzene.

Conflicts of Interest: The authors declare no conflict of interest.

\section{References and Notes}

1. Raoufmoghaddam, S.; Zhou, Y.-P.; Wang, Y.; Driess, M. N-heterocyclic silylenes as powerful steering ligands in catalysis. J. Organomet. Chem. 2017, 829, 2-10. [CrossRef]

2. Tacke, R.; Ribbeck, T. Bis(amidinato)- and bis(guanidinato)silylenes and silylenes with one sterically demanding amidinato or guanidinato ligand: Synthesis and reactivity. Dalton Trans. 2017, 46, 13628-13659. [CrossRef]

3. Zhou, Y.-P.; Driess, M. Isolable Silylene Ligands Can Boost Efficiencies and Selectivities in Metal-Mediated Catalysis. Angew. Chem. Int. Ed. 2018, 58, 3715-3728. [CrossRef] [PubMed]

4. Fujimori, S.; Inoue, S. Small Molecule Activation by Two-Coordinate Acyclic Silylenes. Eur. J. Inorg. Chem. 2020, 3131-3142. [CrossRef]

5. Shan, C.; Yao, S.; Driess, M. Where silylene-silicon centres matter in the activation of small molecules. Chem. Soc. Rev. 2020, 49, 6733-6754. [CrossRef] [PubMed]

6. Zark, P.; Schäfer, A.; Mitra, A.; Haase, D.; Saak, W.; West, R.; Müller, T. Synthesis and reactivity of N-aryl substituted $N$-heterocyclic silylenes. J. Organomet. Chem. 2010, 695, 398-408. [CrossRef]

7. Reiter, D.; Holzner, R.; Porzelt, A.; Altmann, P.J.; Frisch, P.; Inoue, S. Disilene-Silylene Interconversion: A Synthetically Accessible Acyclic Bis(silyl)silylene. J. Am. Chem. Soc. 2019, 141, 13536-13546. [CrossRef]

8. Denk, M.; Lennon, R.; Hayashi, R.; West, R.; Belyakov, A.V.; Verne, H.P.; Haaland, A.; Wagner, M.; Metzler, N. Synthesis and Structure of a Stable Silylene. J. Am. Chem. Soc. 1994, 116, 2691-2692. [CrossRef]

9. Gehrhus, B.; Lappert, M.F.; Heinicke, J.; Boese, R.; Bläser, D. Synthesis, structures and reactions of new thermally stable silylenes. J. Chem. Soc. Chem. Commun. 1995, 1931-1932. [CrossRef]

10. Schäfer, A.; Saak, W.; Weidenbruch, M.; Marsmann, H.; Henkel, G. Compounds of Germanium and Tin, 22-Reactions of a Silyene with a Germylene and a Stannylene: Formation of a Digermene with an Unusual Arrangement of the Substituents and of a Stannane. Chem. Ber. 1997, 130, 1733-1737. [CrossRef]

11. Moser, D.F.; Guzei, I.A. Robert West Crystal Structure of the Stable Silylene, N, N'-di-tert-butyl-1,3-diaza-2silacyclopent-4-en-2-ylidene. Main Group Met. Chem. 2001, 24, 811-812. [CrossRef]

12. Becker, J.S.; Staples, R.J.; Gordon, R.G. Analysis of the crystal structures of 1,3-di-tert-butyl-2,3dihydro-1H-1,3,2-diazasilol-2-ylidene and 1,3-di-tert-butyl-2,2-dichloro-1,3-diaza-2-sila-4-cyclopentene. Cryst. Res. Technol. 2004, 39, 85-88. [CrossRef]

13. Hill, N.J.; Moser, D.F.; Guzei, I.A.; West, R. Reactions of Stable Silylenes with Organic Azides. Organometallics 2005, 24, 3346-3349. [CrossRef]

14. Driess, M.; Yao, S.; Brym, M.; van Wüllen, C.; Lentz, D. A New Type of N-Heterocyclic Silylene with Ambivalent Reactivity. J. Am. Chem. Soc. 2006, 128, 9628-9629. [CrossRef] [PubMed]

15. Kong, L.; Zhang, J.; Song, H.; Cui, C. N-Aryl substituted heterocyclic silylenes. Dalton Trans. 2009, 5444-5446. [CrossRef] [PubMed]

16. Mitra, A.; Brodovitch, J.-C.; Krempner, C.; Percival, P.W.; Vyas, P.; West, R. A Silyl Radical formed by Muonium Addition to a Silylene. Angew. Chem. Int. Ed. 2010, 49, 2893-2895. [CrossRef]

17. Kosai, T.; Ishida, S.; Iwamoto, T. A Two-Coordinate Cyclic (Alkyl)(amino)silylene: Balancing Thermal Stability and Reactivity. Angew. Chem. Int. Ed. 2016, 55, 15554-15558. [CrossRef]

18. Takeda, N.; Suzuki, H.; Tokitoh, N.; Okazaki, R.; Nagase, S. Reaction of a Sterically Hindered Silylene with Isocyanides: The First Stable Silylene-Lewis Base Complexes. J. Am. Chem. Soc. 1997, 119, 1456-1457. [CrossRef] 
19. Gau, D.; Kato, T.; Saffon-Merceron, N.; Cossío, F.P.; Baceiredo, A. Stable Phosphonium Sila-ylide with Reactivity as a Sila-Wittig Reagent. J. Am. Chem. Soc. 2009, 131, 8762-8763. [CrossRef]

20. Filippou, A.C.; Chernov, O.; Blom, B.; Stumpf, K.W.; Schnakenburg, G. Stable N-Heterocyclic Carbene Adducts of Arylchlorosilylenes and Their Germanium Homologues. Chem. Eur. J. 2010, 16, 2866-2872. [CrossRef]

21. Rodriguez, R.; Gau, D.; Contie, Y.; Kato, T.; Saffon-Merceron, N.; Baceiredo, A. Synthesis of a Phosphine-Stabilized Silicon(II) Hydride and Its Addition to Olefins: A Catalyst-Free Hydrosilylation Reaction. Angew. Chem. Int. Ed. 2011, 50, 11492-11495. [CrossRef] [PubMed]

22. Suzuki, K.; Matsuo, T.; Hashizume, D.; Tamao, K. Room-Temperature Dissociation of 1,2-Dibromodisilenes to Bromosilylenes. J. Am. Chem. Soc. 2011, 133, 19710-19713. [CrossRef] [PubMed]

23. Li, W.; Köhler, C.; Yang, Z.; Stalke, D.; Herbst-Irmer, R.; Roesky, H.W. Synthesis of Cyclic Alkyl(amino) Carbene Stabilized Silylenes with Small N-Donating Substituents. Chem. Eur. J. 2019, 25, 1193-1197. [CrossRef] [PubMed]

24. Nagase, S. Theory and Calculations of Molecules Containing Heavier Main Group Elements and Fullerenes Encaging Transition Metals: Interplay with Experiment. Bull. Chem. Soc. Jpn. 2014, 87, 167-195. [CrossRef]

25. Fischer, R.C.; Power, P.P. $\pi$-Bonding and the Lone Pair Effect in Multiple Bonds Involving Heavier Main Group Elements: Developments in the New Millennium. Chem. Rev. 2010, 110, 3877-3923. [CrossRef] [PubMed]

26. Rivard, E.; Power, P.P. Multiple Bonding in Heavier Element Compounds Stabilized by Bulky Terphenyl Ligands. Inorg. Chem. 2007, 46, 10047-10064. [CrossRef] [PubMed]

27. Power, P.P. Stable Two-Coordinate, Open-Shell (d1-d9) Transition Metal Complexes. Chem. Rev. 2012, 112, 3482-3507. [CrossRef]

28. Yoshifuji, M. Sterically protected organophosphorus compounds of unusual structures. Pure Appl. Chem. 2017, 89, 281-286. [CrossRef]

29. Kira, M.; Ishida, S.; Iwamoto, T.; Kabuto, C. The First Isolable Dialkylsilylene. J. Am. Chem. Soc. 1999, 121, 9722-9723. [CrossRef]

30. Abe, T.; Tanaka, R.; Ishida, S.; Kira, M.; Iwamoto, T. New Isolable Dialkylsilylene and Its Isolable Dimer That Equilibrate in Solution. J. Am. Chem. Soc. 2012, 134, 20029-20032. [CrossRef]

31. Kobayashi, R.; Ishida, S.; Iwamoto, T. An Isolable Silicon Analogue of a Ketone that Contains an Unperturbed $\mathrm{Si}=$ O Double Bond. Angew. Chem., Int. Ed. 2019, 58, 9425-9428. [CrossRef] [PubMed]

32. Asay, M.; Inoue, S.; Driess, M. Aromatic Ylide-Stabilized Carbocyclic Silylene. Angew. Chem. Int. Ed. 2011, 50, 9589-9592. [CrossRef] [PubMed]

33. Mizuhata, Y.; Sasamori, T.; Tokitoh, N. Stable Heavier Carbene Analogues. Chem. Rev. 2009, 109, 3479-3511. [CrossRef] [PubMed]

34. Sasamori, T.; Tokitoh, N. A New Family of Multiple-Bond Compounds between Heavier Group 14 Elements. Bull. Chem. Soc. Jpn. 2013, 86, 1005-1021. [CrossRef]

35. Iwamoto, T.; Ishida, S. Multiple Bonds with Silicon: Recent Advances in Synthesis, Structure, and Functions of Stable Disilenes. In Functional Molecular Silicon Compounds II: Low Oxidation States; Scheschkewitz, D., Ed.; Structure and Bonding; Springer International Publishing: Cham, Switzerland, 2014; pp. 125-202. ISBN 978-3-319-03734-9.

36. Ishida, S.; Iwamoto, T. Recent advances in $\eta 2$-disilene and $\eta 2$-disilyne mononuclear transition metal complexes and related compounds. Coord. Chem. Rev. 2016, 314, 34-63. [CrossRef]

37. Matsuo, T.; Hayakawa, N. $\pi$-Electron systems containing Si=Si double bonds. Sci. Technol. Adv. Mater. 2018, 19, 108-129. [CrossRef]

38. Rammo, A.; Scheschkewitz, D. Functional Disilenes in Synthesis. Chem. Eur. J. 2018, 24, 6866-6885. [CrossRef]

39. Sasamori, T. Ferrocenyl-substituted low-coordinated heavier group 14 elements. Dalton Trans. 2020, 49, 8029-8035. [CrossRef]

40. Sasamori, T.; Suzuki, Y.; Sakagami, M.; Miyake, H.; Tokitoh, N. Structure of stable telluradiphosphirane bearing bulky ferrocenyl ligands. Chem. Lett. 2014, 43, 1464-1466. [CrossRef]

41. Sakagami, M.; Sasamori, T.; Sakai, H.; Furukawa, Y.; Tokitoh, N. 1,2-Bis(ferrocenyl)dipnictenes: Bimetallic Systems with a Pn= Pn Heavy $\pi$-Spacer (Pn: P, Sb, and Bi). Bull. Chem. Soc. Jpn. 2013, 86, 1132-1143. [CrossRef]

42. Sasamori, T.; Suzuki, Y.; Tokitoh, N. Isolation and Structural Characterization of a Lewis Base-Free Monolithioferrocene. Organometallics 2014, 33, 6696-6699. [CrossRef] 
43. Suzuki, Y.; Sasamori, T.; Guo, J.-D.; Tokitoh, N. A Redox-Active Bis(ferrocenyl)germylene and Its Reactivity. Chem. Eur. J. 2018, 24, 364-368. [CrossRef] [PubMed]

44. Herberhold, M.; Ayazi, A.; Milius, W.; Wrackmeyer, B. Silyl derivatives of ferrocene with pending indenyl or fluorenyl substituents at silicon. J. Organomet. Chem. 2002, 656, 71-80. [CrossRef]

45. $\mathrm{Fc}^{*}(\mathrm{Fc}) \mathrm{Si}(\mathrm{OH})_{2}$ was characterized based on the spectroscopic and XRD analyses. See the Material and Methods section.

46. Crystallographic data for 5, 9a, 10, 11, 13, 14, and $\mathrm{Fc}^{*} \mathrm{FCSi}(\mathrm{OH})_{2}$ were deposited at the Cambridge Crystallographic Data Centre (CCDC) under the numbers CCDC-2044338-2044344. These data can be obtained free of charge via www.ccdc.cam.ac.uk/structures.

47. Suzuki, H.; Tokitoh, N.; Okazaki, R. A Novel Reactivity of a Silylene: The First Examples of [1 + 2] Cycloaddition with Aromatic Compounds. J. Am. Chem. Soc. 1994, 116, 11572-11573. [CrossRef]

48. Kira, M.; Ishida, S.; Iwamoto, T.; Kabuto, C. Excited-State Reactions of an Isolable Silylene with Aromatic Compounds. J. Am. Chem. Soc. 2002, 124, 3830-3831. [CrossRef] [PubMed]

49. Fukuoka, T.; Uchida, K.; Sung, Y.M.; Shin, J.-Y.; Ishida, S.; Lim, J.M.; Hiroto, S.; Furukawa, K.; Kim, D.; Iwamoto, T.; et al. Near-IR Absorbing Nickel(II) Porphyrinoids Prepared by Regioselective Insertion of Silylenes into Antiaromatic Nickel(II) Norcorrole. Angew. Chem. Int. Ed. 2014, 53, 1506-1509. [CrossRef] [PubMed]

50. Kosai, T.; Ishida, S.; Iwamoto, T. Transformation of azulenes to bicyclic [4]dendralene and heptafulvene derivatives via photochemical cycloaddition of dialkylsilylene. Chem. Commun. 2015, 51, 10707-10709. [CrossRef]

51. Xiong, Y.; Yao, S.; Driess, M. Versatile Reactivity of a Zwitterionic Isolable Silylene toward Ketones: Silicon-Mediated, Regio- and Stereoselective C-H Activation. Chem. Eur. J. 2009, 15, 5545-5551. [CrossRef]

52. Azhakar, R.; Ghadwal, R.S.; Roesky, H.W.; Mata, R.A.; Wolf, H.; Herbst-Irmer, R.; Stalke, D. Reaction of N-Heterocyclic Silylenes with Thioketone: Formation of Silicon-Sulfur Three (Si-C-S)- and Five (Si-C-C-C-S)-Membered Ring Systems. Chem. Eur. J. 2013, 19, 3715-3720. [CrossRef]

53. Frisch, M.J.; Trucks, G.W.; Schlegel, H.B.; Scuseria, G.E.; Robb, M.A.; Cheeseman, J.R.; Scalmani, G.; Barone, V.; Petersson, G.A.; Nakatsuji, H.; et al. Gaussian 16, Revision C.01; Gaussian, Inc.: Wallingford, CT, USA, 2016.

54. Sheldrick, G.M. A short history of SHELX. Acta Cryst. 2008, 64, 112-122. [CrossRef]

55. Sheldrick, G.M. SHELXT-Integrated space-group and crystal-structure determination. Acta Cryst. 2015, 71, 3-8. [CrossRef] [PubMed]

Sample Availability: Sample of compound 4 is available from the authors.

Publisher's Note: MDPI stays neutral with regard to jurisdictional claims in published maps and institutional affiliations.

(C) 2020 by the authors. Licensee MDPI, Basel, Switzerland. This article is an open access article distributed under the terms and conditions of the Creative Commons Attribution (CC BY) license (http://creativecommons.org/licenses/by/4.0/). 